\title{
The Effect of Integrity, And Discipline on Quality of Work Life (Qwl) Government Internal Supervision Officers Republic of Indonesia Ministry of Law and Human Rights
}

\author{
${ }^{1}$ Joko Martanto ${ }^{*}{ }^{2}$ Syarifuddin Tippe, ${ }^{3}$ Budi Santoso \\ ${ }^{1,2,3}$ Universitas Negeri Jakarta, Jakarta
}

\begin{abstract}
The purpose of this research is to describe and analyze the influence of integrity and discipline of quality of work life (QWL). This research used a quantitative approach with survey methods. The samples of this research are the whole 132 government internal supervision officers Republic of Indonesia Ministry of Law and Human Rights which was performed randomly simple. The results showed that; (1) There is a direct positive influence integrity of the quality of work life (QWL); (2) There is no direct positive influence discipline of the quality of work life (QWL); (4) There is no direct positive influence transformational leadership of the discipline; (3) There is a direct positive influence integrity of the discipline; and (4) There is no indirect positive influence integrity of the quality of work life (QWL) through discipline. To improve the quality of work life (QWL), need to improve the integrity and discipline.
\end{abstract}

Keywords: Integrity, Discipline, Quality of Work Life

\section{Introduction}

An organization needs a balance between quality of work life (QWL) with well-being. QWL aims to understand human behavior in the workplace and ways to improve the well-being, balance between the productivity of the achievement of organizational goals. Quality of work life (QWL) relating to the working conditions comfortable, pleasant working conditions, involvement maximum work that was included in the organization.

Seeing the importance of QWL, Alqarni (2016) in his research it is said that "Low QWL causing dissatisfaction in work, increase employee absenteeism, lack of motivation to work, have a negative moral, lack of productivity, and poor performance of the organization". as according to Singhapakdi, et. al, (2015) that the "quality of work life (QWL) as a form of employee satisfaction by fulfilling various needs resources, activities, and increased quality in the workplace. This is according to the results of research Razak (2016) which says that "QWL as a form of employee satisfaction with various needs through the resources, activities and results that come from participation in the workplace".

The reason researchers conducted a study in government internal supervision officers Republic of Indonesia of the Ministry of Justice and Human Rights of the Republic of Indonesia because there are some problems that occur. Based on the results of the study found to be associated pre QWL including; the high labor intensity of government internal supervision officers Republic of Indonesia, a workload that many causes frequent overtime work, this is the condition causing no majority government internal supervision officers Republic of Indonesia who fell ill. In addition, the welfare of the employees are also not balanced between the workloads, longer work and their salary, working conditions are less comfortable because there are several groups of fellow employees of the main groups of senior and junior group were still a few years of working so that the occurrence of unfair competition.

Problems also occur on aspects of employee integrity. Based on the results of pre-study found that there are some employees who do not have integrity in their work as in monitoring dishonest because supervised has a close relationship with regulatory authorities, there are also some supervisors when return service from out 
of town do not go directly to the office when the clock office still exists, dishonest conduct surveillance while in the field, not transparent about the weakness and lack of time to supervise.

Discipline is an attitude of willingness to comply with all the rules and norms that exist in the line of duty as a form of responsibility. The success of the regulatory process depends on several factors including the factor of discipline. Disciplinary government internal supervision officers Republic of Indonesia also became one of the most important to be owned by the government internal supervision officers Republic of Indonesia Ministry of Law and Human Rights.

\section{Literature Review}

\section{Quality of Work Life (QWL)}

The term quality of work life (QWL) was first introduced at the International Labor Conference in 1972, but only gained attention after the United Auto Workers and General Motors took the initiative to adopt practices to change the quality of working life working system. There are several definitions of quality of work life (QWL) among others; according to Razak, et. al. (2016) that a favorable working conditions for employees, provide benefits to employees, and well-being so that the balance between work with the needs of family life. The term quality of work life (QWL) refers to the working environment for employees.

The same thing was said by Singhapakdi, et. al (2015) that the employee satisfaction towards fulfilling the needs of the family, health, safety, economic needs, self-actualization, and increase employee knowledge. According to Gibson (2012) that the Quality of Work Life (QWL) is a management philosophy that should enhance the dignity of employees, introducing cultural change and provide an opportunity for employees to develop. One of the most important of the quality of work life (QWL) is the use of leave, and the number of complaints filed.

According to Farid (2015) that the Quality of Work Life (QWL) in an effort to improve the quality of the organization and take advantage of the benefits of an organization. Quality of work life (QWL) is the center of attention for the employees so that its role can be enhanced and increase their participation in the development of the organization. Similar feelings were expressed by Khashman, et. al, (2017) that a work situation or development reflects an increase in all elements of the organization and the basics of the environment to ensure all employees to be able to adapt, and increase the potential of human resources.

According to Ehnert, et. al (2014) that as employee perceptions about their well-being in the workplace. In line with these opinions, Luthans and Jonathan (2012) also says that a management required for success. Seeing the importance of Quality of Work Life (QWL).

\section{Integrity}

According to Elsetouhi, et. al (2017) that the integrity associated with various values relating to the construction, morality, honesty, ethical, and sincerity. The word integrity is not just a matter of honesty, ethical and moral issues that people do not lie or do anything immoral.

According to Cheng, et. al (2014) that the integrity implies that individual behavior is consistent with the values of honesty and trustworthy. At the individual level, the integrity of an ethics, character, honest, ethical, transparent and credible. This is in accordance opinions Roslia et. al (2015) that the integrity of the building within an organization to foster mutual trust between leaders and subordinates.

This is in accordance opinions Mustaffa et. al (2015) that the confidence, competence, professionalism, and confidence is an indicator of integrity. Further according to Nankervis, et. al (2016) that integrity means working attitude that promotes values of fairness, honesty, legality, respect for individual rights, legal, ability, work to increase trust, professional, loyal, and respect for fellow employees. Integrity is a must to be possessed by every employee in an organization. This is because the integrity leads to compliance with the code of conduct and ethical principles.

According to Timothy (2015) that the integrity behavior can thrive when leaders can to cultivate them to speak and behave. Integrity in the broadest sense, is known as the key to the development of an organization. Without integrity possessed an employee will cause a slump value of the productivity of the organization, because of corruption, nepotism, and the establishment of good working culture. Integrity is very important in establishing a good and moral character. Integrity 'can also be formed and planned like 
doing character education training employees and it's all included as organizational management and responsibility.

\section{Discipline}

Etymologically, Mangkunagara and Warris, (2015) that the discipline is a person's attitude and willingness to comply with a rule and norms in the vicinity. Discipline is very important for any group, community and organization. Then discipline is one of the basic symbol of social life. Further according to Ugurlu et. al (2015) that the observance of discipline used in a rule.

This is according to a statement Ivancevich and Konopaske (2013) that the rules governing the discipline as a manifestation of behavior, discipline is a very important part in the social life of the community. Further according to Dessler (2014) that the purpose of discipline is to encourage employees to abide by the rules and regulations. Discipline is required when an employee who violates any of the rules that have been determined.

According to Dessler (2013) that the purpose of discipline is to encourage employees to exercise prudence in the work place. Further according to Roberts (2015) that management discipline applied to meet the standards of performance, breach or violation of rules of ethics and morals. This is in accordance opinions Roberts (2015) that the discipline required for the interests and welfare of employees and the organization's survival.

The statement was supported by Sennewald and Baillie (2016) that the majority of these explanations emphasize punishment or control which aims to build discipline. According to Kabukcu (2015) that the discipline as a systematic process for applying creativity and innovation to meet the needs and opportunities. Likewise by Likeschova and Ticha (2013) that are necessary for the development of creativity is spontaneity, confidence, respect, given enough time, accept the failure, the willingness to defend against convention and behave discipline. Further according to Chen, et. al (2013) that individual creativity is influenced by personality factors, cognitive styles and abilities, discipline skills related to the duties, the motives and the impact of social context.

\section{Research Method}

The method in this research is the survey will be analyzed using path analysis (path analysis). Questionnaires were used to obtain research data consists of three variables, namely: quality of work life (QWL) (Y), integrity (X1), discipline (X2). Inferential analysis using Structural Equation Modeling (SEM) based variant or component-based. Analysis of the data used in this study using Partial Least Square approach. This research was conducted in the government internal supervision officers Republic of Indonesia of the Ministry of Justice and Human Rights of the Republic of Indonesia The number of research subjects sampled in this study was about 132 officers.

\section{Results and Discussion of Research}

The results obtained after analyzing the model used as the basis for answering hypotheses and draw conclusions in this study. The explanation for the answer hypothesis can be described as follows:

\section{Direct Influence of Positive Integrity to Quality Work of Life}

The first hypothesis testing results show that the relationship of integrity for QWL variables show path coefficient value of 0467 with a value of $t$ count equal to 7645 and a $p$-value of $0.000 .7645 \mathrm{t}$ count $>\mathrm{t}$ table 1.665. The results in this study that the integrity of the positive and significant effect on the QWL means in accordance with the second hypothesis where integrity has been able to push the QWL. This means that the first hypothesis is accepted.

\section{Direct Influence of Positive Discipline to Work Quality of Life}

The second hypothesis testing results show that the relationship variables QWL discipline shows the value of the path coefficient is 0.025 with a t value of 0.292 and $p$ value of 0.770 . T value $0.292<t$ table 1.665. The results in this study that discipline is not positive and not significant to the QWL which means not in accordance with the third hypothesis where discipline was unable to push the QWL. This means that the second hypothesis is rejected.

\section{Direct Influence of Positive Integrity to Discipline}


The third hypothesis testing results show that the variable relationship of integrity for the discipline showed the path coefficient value of 0195 with a value of $t$ count equal to 2,037 and $p$ value of 0.042 . T value 2,037> t table 1.665. The results in this study that the integrity of positive and significant influence on the discipline, which means according to the fifth hypothesis where integrity has been able to encourage discipline. This means that the third hypothesis is accepted.

\section{Direct Influence of Positive Integrity to Quality of Work Life through Discipline}

The fourth hypothesis testing to test the integrity of the indirect effect of the QWL variables through the discipline of using smart PLS indicates that the path coefficient value of 0.002 with a $t$ value of 0.220 while the $\mathrm{p}$ value 0826 . T value $0.220<\mathrm{t}$ table 1.665 . This result means that the integrity is not positive and not significant to the QWL through discipline means in accordance with the ninth hypothesis which integrity is able to push the QWL mediated by discipline.

Tests on the influence of mediation between the intervening variable and dependent variable is done by calculating the formula Sobel. T value of 0262 is smaller than 1,665, which means that the parameters of mediation are not positive and not significant. There by, the use of test equipment and smart PLS Sobel formula hypothesis 4 was rejected.

\section{Conclusion}

This study is intended to look for factors that could affect the quality of work life (QWL) in Ministry of Justice and Human Rights of the Republic of Indonesia include:

1. The first hypothesis test results indicate that there are significant integrity to the quality of work life (QWL) in Ministry of Justice and Human Rights of the Republic of Indonesia to the level of a coefficient of0, 467. It shows if the integrity is executed properly it will lead to increased quality of work life (QWL).

2. The second hypothesis test results indicate that there is no influence of discipline to the quality of work life (QWL) at the Ministry of Justice and Human Rights of the Republic of Indonesia to the level of a coefficient of 0,025 . This suggests that the discipline does not lead to increased quality of work life (QWL).

3. The third hypothesis test results indicate that there are significant integrity towards discipline in the Ministry of Justice and Human Rights of the Republic of Indonesia to the level of a coefficient of 0.195. It shows if the integrity is executed properly it will lead to increased discipline.

4. The fourth hypothesis test results show that there is an indirect effect of integrity to the quality of work life (QWL) through discipline in the Ministry of Justice and Human Rights of the Republic of Indonesia to the level of a coefficient of0.002. It was concluded that discipline cannot mediate the effect of the integrity of the quality of work life (QWL).

\section{Recommendation}

Based on empirical findings obtained from this study, researchers delivered some advice to the effect of integrity and discipline quality of work life (QWL) at the Ministry of Justice and Human Rights Affairs, as follows:

1. Integrity conditions should be improved because it proved a positive direct impact on the quality of work life (QWL) at the Ministry of Justice and Human Rights of the Republic of Indonesia.

a. Government internal supervision can be ethically good to fellow employees or management.

b. Government internal supervision can be trusted when given the mandate or duty that must be carried.

2. Disciplinary conditions should be improved because it proved a positive direct impact on the quality of work life (QWL) at the Ministry of Justice and Human Rights RI

a. Government internal supervision in order to be submissive and obedient to the rules set by the leaders.

b. Government internal supervision can be expected to follow instructions led to the development potential and organizational development. 
c. Government internal supervision can be expected to come and go home on time.

3. Aspects that need to be considered and improved on variables Quality of work life (QWL) is the indicator of well-being, participation in the workplace, safety and safe working conditions, health insurance, have the opportunity to learn and work balanced with the need.

4. Would need to do further research by other researchers who are interested in researching the problem of performance by considering the involvement of other variables that potentially influence the Quality of Work Life (QWL). Besides, it can be done using more samples and spacious. It aims to get the results more accurate and comprehensive.

\section{References}

[1.] Alqarni, Saleh Ali Y. (2016). Quality of Work Life as a Predictor of Work Engagement among the Teaching Faculty at King Abdul Aziz University. International Journal of Humanities and Social Science.

[2.] Singhapakdi, Anusorn, M. Joseph Sirgy, Ong-Jin Lee, Kalayanee Senasu. (2015). The Impact of Incongruity Between An Organization's Csr Orientation and Its Employees' CSR Orientation On Employees' Quality Of Work Life. Journal of Business Research.

[3.] Razak, Norfadzilah Abdul, Hairunnisa Ma'amor, Narehan Hassan. (2016). Measuring Reliability and Validity Instruments of Work Environment towards Quality Work Life. International Journal Procedia Economics and Finance.

[4.] Gibson, James L, John Ivancevic, James H. Donnelly, Robert Konopaske. (2012). Organizations Behavior, Structure, Processes. New York: McGraw-Hill.

[5.] Farid, Hadi. (2015). Relationship Between Quality of Work Life and Organizational Commitment Among Lecturers in a Malaysian Public Research University. The Social Science Journal.

[6.] Khashman, Aysar Feras Ali Alzubi, Abdelmutti Assaf, Ayyoub Alsawalhah. (2017). The Main Resources of Diversity and Its Effects on the Quality of Work Life of Human Resources. International Journal of Advanced Research (IJAR).

[7.] Ehnert, Ina, West Harry, Klaus, J Zink. (2014). Sustainability and Human Resource Management. New York: Springer Heidelberg.

[8.] Luthans, Fred dan Jonathan P. Doh. (2012). International Management. New York: McGraw-Hill Irwin.

[9.] Elsetouhi, Ahmed M. Abdelhakim Ahmed Nagm, Ahmed Hammad, Ahmed Mohamed Elbaz. (2017). Perceived Leader Behavioral Integrity and Employee Voice in SMEs Travel Agents: The Mediating Role of Empowering Leader Behaviors. International Journal Tourism Management.

[10.] Cheng, Chi-Ying, Ding-Yu Jiang, Bor-Shiuan Cheng, Jean h. Riley, Chin-Kang Jen. (2014). When Do Subordinates Commit To Their Supervisors? Different Effects Of Perceived Supervisor Integrity And Support on Chinese and American Employees. International Journal The Leadership Quarterly.

[11.] Roslia, Mohamad Hafiz, Mohamad Azizal bin Abd Aziz, Farah Wahida Mohd Jamaliah Said. (2015). Integrity Systems in Malaysian Public Sector: An Empirical Finding. International Journal Procedia Economics and Finance.

[12.] Bakri, Haniza Hanim Mustaffa, Jamaliah Said. Zulyanti Abd Karim. (2015). Case Study on Integrity among Royal Malaysian Police (RMP): An Ethical Perspective. International Journal Procedia Economics and Finance.

[13.] Nankervis, Alan, Chris Rowley, Noorziah Mohd Sall. (2016). Asia pacific Human Resource Management and Organisational Effectiveness. Cambridge: Chandos Publishing.

[14.] Hinkin, Timothy R. Chester A. Schriesheim. (2015). Leader Reinforcement, Behavioral Integrity, And Subordinate Outcomes: A Social Exchange Approach. International Journal The Leadership Quarterly.

[15.] [Mangkunegara, Anwar Prabu dan Abdul Warris. (2013). Effect of Training, Competence and Discipline on Employee Performance in Company. International Journal Procedia - Social and Behavioral Sciences. 
[16.] Ugurlu, Celal Teyyar, Yasar Kondakci, Kadir Beycioglu, Mehmet Sincar. (2015). The Views of Teachers Towards Perception of Discipline in Schools. International Journal Procedia - Social and Behavioral Sciences.

[17.] Ivancevich, John M. and Robert Konopaske. (2013). Human Resource Management. New York: McGraw-Hill.

[18.] Dessler, Gary. (2014). Fundamentals of Human Resource Management. London: Pearson Education Limited.

[19.] Dessler, Gary. (2013). Human Resource Management. New Jersey: Pearson Education.

[20.] Roberts, Gary E. (2015). Human Resource Management. New York: Palgrave Macmillan.

[21.] Sennewald, Charles A. and Curtis Baillie. (2016). Effective Security Management. Lane: Kidlington: Elsevier.

[22.] Kabukcu, Evrim. (2015). Creativity Process In Innovation Oriented Entrepreneurship: The case of Vakko. Procedia-Social and Behavioral Sciences.

[23.] Likeschova, Dana, Alena Ticha. (2013). Multicultural Education, Creativity and Innovation at Universities in the Czech Republic. Procedia-Social and Behavioral Sciences.

[24.] Chen, Ailing, Liping Li Xingsen Li, Jun Zhang, Lei Dong. (2013). Study on Innovation Capability of College Students Based on Extenics and Theory of Creativity. Procedia Computer Science. 